\title{
Study of meteorological drought and its impact on rainfed paddy productivity in Gunungkidul Regency
}

\author{
Qooi Insanu Putra, and Emilya Nurjani* \\ Department of Environmental Geography, Faculty of Geography, Universitas Gadjah Mada, Indonesia
}

\begin{abstract}
Gunungkidul Regency is known as an area that often experiences drought. On the other hand, Gunungkidul Regency is also the regency with the highest amount of rice production in the Special Region of Yogyakarta Province. Rainfed paddy farming is the most widely developed type of paddy in Gunungkidul Regency where irrigation needs are determined by rainfall. Decreased rainfall that triggers meteorological drought can disrupt rainfed-based agriculture. This study aims to analyze the distribution of meteorological drought and analyze the impact of meteorological drought on rainfed paddy productivity in Gunungkidul Regency during the period 2001 - 2019. Meteorological drought identification was carried out using the Standardized Precipitation Index (SPI). Results of the SPI classification was mapped using Spline-Tension interpolation for spatial analysis of the distribution of meteorological drought. Spatial analysis and comparison graphs were used to analyze the relationship between drought and rainfed paddy productivity. The widest meteorological drought in Gunungkidul Regency occurred in November 2006. The highest frequency of drought events occurred in Paliyan Sub-district for 50 months while the lowest occurred in Ponjong Sub-district for 30 months. Most sub-districts in Gunungkidul Regency have a positive relationship between meteorological drought. Most of rainfed paddy productivity decreased when El Nino occurred.
\end{abstract}

\section{Introduction}

Drought is a condition of lack of water resources in an area caused by rainfall conditions that are below the normal average at a certain time scale continuously [1]. The climate anomaly caused by the El Nino phenomenon can exacerbate the occurrence of droughts because it will accelerate the onset of the dry season and the next rainy season will come later than normal conditions $[2,3]$. In relation to drought, El Nino is a phenomenon that is one of the biggest factors causing drought in Indonesia because El Nino has an impact on reducing the amount of rainfall from its normal condition [4]. On the other hand, La Nina has an impact on increasing rainfall so that from a drought perspective, La Nina events will minimize the occurrence of drought events.

Several studies have shown a strong correlation between the ENSO phenomenon and the accompanying climate anomalies with food problems in the world, which mainly occur in developing countries with the majority being agricultural countries that rely on the agricultural sector $[5,6]$. One type of drought that can be an early indicator of drought is meteorological drought [7].

Global climate disturbances caused by the ENSO phenomenon have had an impact on the life sector in Indonesia, especially related to food issues [2]. Agricultural sector is one of the sectors affected because it has a direct relationship with various weather and climate factors, making it quite vulnerable to weather and climate disturbances [4]. The effects of climate change on the agricultural sector are multidimensional, ranging from resources, agricultural infrastructure, agricultural production systems, to aspects of food security and self-sufficiency, as well as the welfare of farmers and society in general [8].

For farmers, the occurrence of rain becomes a reference for planting which will be used to increase the water content or soil moisture [4]. Changes in the pattern and distribution of rainfall can result in a shift in the beginning of the season and the planting period [9]. According to [10], a decrease in rainfall can reduce the potential for one period of rice planting. These results provide information that climate disturbances can have a real impact on the agricultural sector because they can reduce agricultural production and productivity. It is feared that the decline in paddy production and productivity in a sustainable manner will disrupt food security in the future.

One of the impacts of weather and climate disturbances on agriculture is the expansion of crop failure land in Gunungkidul Regency which is strongly suspected to be caused by weather conditions that cannot be predicted with certainty. Gunungkidul Regency experienced a significant expansion of crop failure land over the past three years due to the early dry season.

According to [11], Gunungkidul Regency is one of the areas known as a barren area and prone to drought

* Corresponding author: emilya.nurjani@ugm.ac.id 
caused by the low intensity of rainfall in the dry season. On the other hand, Gunungkidul Regency is also one of the regencies with the highest rice production in the Special Region of Yogyakarta (DIY) with the total production in 2019 reaching 201,654 tons [12]. In percentage terms, Gunungkidul Regency supplies around $37.79 \%$ of the total rice production in the DIY Province [12].

Weather and climatic conditions in Indonesia which are influenced by various global climate dynamics as described above are expected to cause various impacts including the intensity of meteorological drought events and disturbances to the productivity of rainfed paddy in the research location. The importance of the agricultural sector in Gunungkidul Regency as the fulfilment of the largest food needs in DIY Province makes it important to study the meteorological drought events and also its causes because it is thought to have a direct impact on various vulnerable sectors, mainly related to rainfed paddy productivity.

Based on these conditions, this study will identify the distribution of meteorological drought events in Gunungkidul Regency and see its impact on rainfed paddy productivity which is the largest food source in Gunungkidul Regency.

\section{Methods}

\subsection{Research location}

The research was conducted by taking Gunungkidul Regency as the research location. Gunungkidul Regency is one of the regencies in the Special Region of Yogyakarta Province which is located in the UTM position zone 49M 425415mT - 493513mT to $9091415 \mathrm{mU}-9139903 \mathrm{mU}$. Gunungkidul Regency has an area of $1,485.36 \mathrm{~km}^{2}$ which makes it the largest regency in the Special Region of Yogyakarta Province with a percentage of $46 \%$ of the total area of the Special Region of Yogyakarta Province. Gunungkidul Regency consists of 18 sub-districts including Panggang, Purwosari, Paliyan, Saptosari, Tepus, Tanjungsari, Rongkop, Girisubo, Semanu, Ponjong, Karangmojo, Wonosari, Playen, Patuk, Gedangsari, Nglipar, Ngawen and Semin. The Administrative area of Gunungkidul Regency is shown in Figure 1.

Gunungkidul Regency was chosen as the research location by considering the characteristics of the dry area so that it is prone to drought [13]. This condition makes the agricultural land that is widely developed in Gunungkidul Regency is rainfed or dryland-based agricultural [14].

In addition, Gunungkidul Regency is a regency that has the largest total harvested area and rice production in the Special Region of Yogyakarta Province. Food and agriculture data from the Central Bureau of Statistics (CBS) shows that during 2001 - 2019, Gunungkidul Regency became the regency with the largest paddy harvest area in the Special Region of Yogyakarta Province. According to [12], agricultural data during that period also shows that around $75 \%$ of the harvested area for paddy farming in Gunungkidul Regency is rainfed paddy farming. This is different from the condition of other regencies and cities in Special Region of Yogyakarta Province which on average only has a percentage of rainfed paddy farming area of $1 \%$ of the total area.

Rainfed paddy farming is dependent on rainfall to meet its irrigation needs so that it is prone to drought. The existence of an anomaly of rainfall that causes drought, is indicated to be the main factor causing farmers to fail to harvest in Gunungkidul Regency at several harvest season.

\subsection{Research method}

This research is classified as a quantitative descriptive research, that is, the analysis is described from the results of processing numerical data which results in a pattern of interrelationships between one another and compared with the other research and literatures. The final result of this research is a description of the study of meteorological drought and its impact on rainfed paddy agriculture in Gunungkidul Regency. To realize these results, the stages of research that will be carried out are: (1) Data Collection, (2) Data Processing, and (3) Data Analysis.

\subsection{Research data}

Research analysis was carried out during 2001 - 2019 considering the condition of regional expansion in Gunungkidul Regency which was divided into 18 subdistricts since regional autonomy was enacted in 2001. This is related to the availability of data in each subdistrict which will become the unit of analysis for research analysis. In addition, the year selection is also based on the frequency of ENSO events where during 2001 - 2019 there have been several El Nino and La Nina events in weak, moderate, and strong classifications so that they may have an impact on meteorological drought in Gunungkidul Regency.

The research was conducted by processing various basic data that became the research material. This study uses secondary data obtained from various agency publications and research literature studies, including: monthly rainfall, rainfed paddy productivity, shapefile (.shp), and Southern Oscillation Index (SOI) data.

Monthly rainfall data during 2001 - 2019 was obtained from the publication of the Agriculture and Food Office of Gunungkidul Regency at rain stations spread over 18 sub-districts in Gunungkidul Regency. Data on rainfed paddy productivity during $2001-2019$ was obtained from the Agriculture and Food Office of Gunungkidul Regency in the CBS Publications of 2001 - 2019. Shapefile data was collected from National Mapping Agency of Indonesia that used as mapping data. Monthly SOI data during $2001-2019$ is sourced from the official website of the Australian Bureau of Meteorology. In this study, SOI data are used as additional data used for identification and analysis of the causes of meteorological drought especially on El Nino phase of ENSO [4]. 


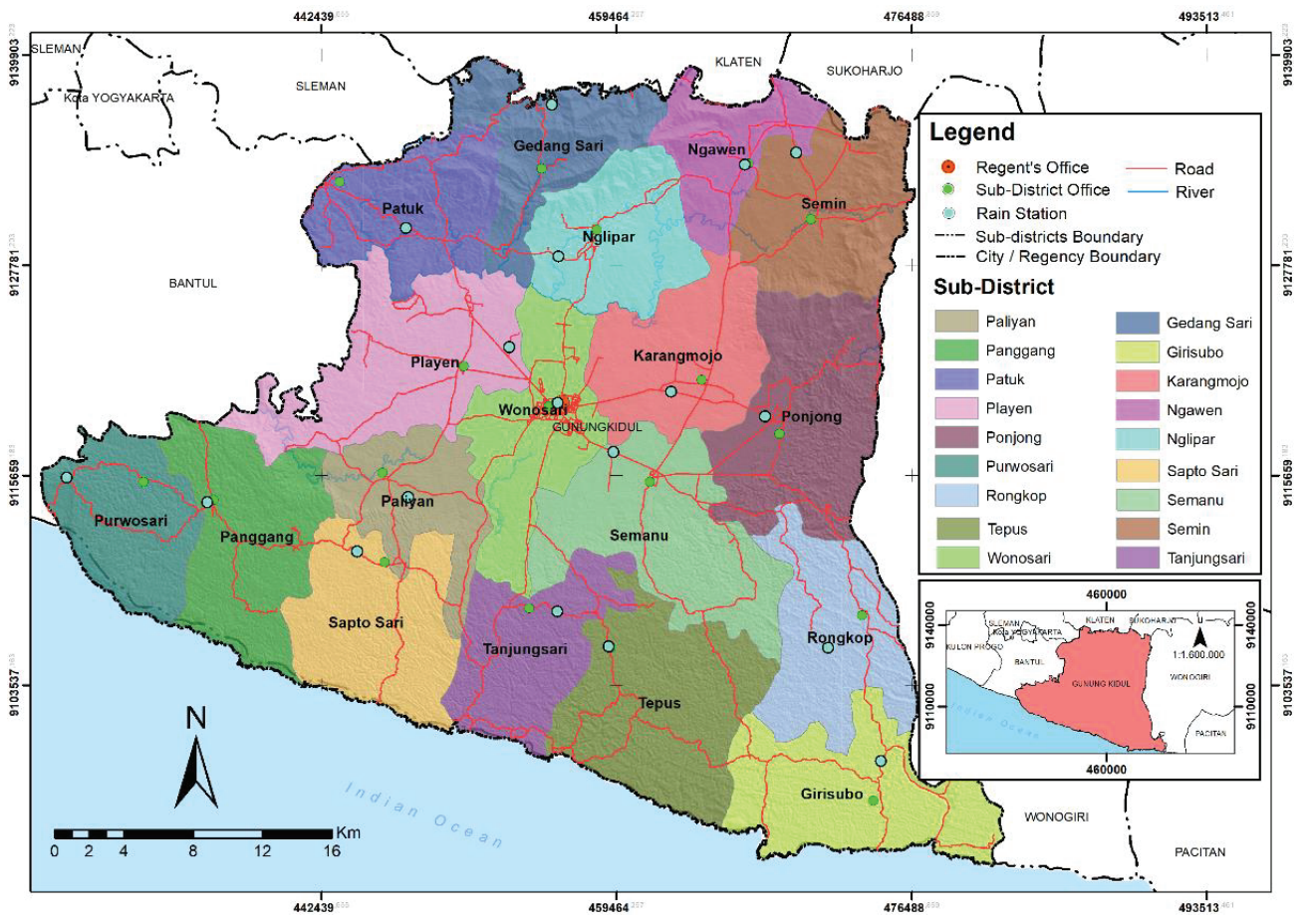

Fig.1. Administration map of Gunungkidul Regency

\section{$2.4 \quad$ Data processing}

First step in the research is to fill in the empty rainfall data. Rainfall data has an important role because it is the main indicator of meteorological drought analysis. One method that can be used is the Inverse Square Distance method. The Inverse Square Distance method is a method of filling in rainfall data by utilizing rain data from adjacent stations [15]. Then, Standardized Precipitation Index (SPI) method is used to determine the classification of meteorological drought at each rain station. According to [16], the classification of SPI values is presented in Table $\mathbf{I}$.

Table 1. Classification of SPI

\begin{tabular}{cll}
\hline Num & Classification & SPI Value \\
\hline 1 & Extremely Wet & $\geq 2$ \\
2 & Very Wet & $1.5-1.99$ \\
3 & Moderately Wet & $1.0-1.49$ \\
5 & Normal & $(-0.99)-0.99$ \\
6 & Moderately Dry & $(-1.0)-(-1.49)$ \\
7 & Severely Dry & $(-1.5)-(-1.99)$ \\
8 & Extremely Dry & $\leq(-2)$ \\
\hline
\end{tabular}

This study uses a six-month SPI (SPI-6) scenario and four-month paddy season (SPI-4) scenario in answering the objectives. The SPI-6 scenario was used to mapping the distribution of drought in various subdistricts in Gunungkidul Regency. The SPI-6 scenario describes a short to medium term meteorological drought that is commonly used to identify droughts affecting agriculture, irrigation, and surface water resources and is ideal for comparing droughts in areas with two different periods $[7,16,17]$.

SPI-4 scenario in the paddy farming season to be adapted to rainfed paddy planting conditions in Gunungkidul Regency which has a paddy growing season of approximately 110-120 days from October to January $[14,18]$. Therefore, SPI-4 in January describes the conditions of the previous 4 months during farming season. The adjustment to the SPI scenario, especially SPI-4 in answering the third objective, is due to the characteristics of the SPI which has the flexibility to be adjusted according to the research objectives $[19,20]$.

Drought mapping was carried out using ArcGIS 10.3. This study uses the Tension Spline interpolation method. Tension Spline was chosen because it has a lower RMSE value than other interpolation methods. Tension Spline interpolation method is considered to have smoother results and lower RMSE levels than other methods [21-24].

Drought mapping focuses on the worst drought in every month throughout 2001 - 2019. The worst drought every month from January to December are known through the results of SPI-6 data processing where the month of the year with the highest number of droughts is identified as the most severe drought month.

\subsection{Research analysis}

Data analysis was carried out through various techniques to examine each unit of research analysis. The unit of analysis used for all purposes emphasizes the administrative unit in the form of a sub-district. The analytical technique used in this research is spatial and associative analysis. 
Spatial analysis was used to explain the distribution of meteorological drought in Gunungkidul Regency. Spatial analysis was carried out on maps that shown the maps of the most severe of meteorological droughts in each month during period $2001-2019$. The mapping is only carried out in the month of the worst drought from the results of the SPI matrix so that it will shows of the worst drought for 12 months from January to December with the year of occurrence that is not always the same.

Associative analysis was used to identify the graph of the relationship between meteorological drought and rainfed paddy productivity. Analysis of the impact on rainfed paddy productivity was also carried out in a spatio-temporal manner to explain the average paddy productivity, especially during certain ENSO phases such as El Nino, La Nina and Normal. This is done to describe descriptively and spatially whether every El Nino occurrence will have an impact on paddy productivity through an intermediate variable in the form of a decrease in rainfall so as to increase the incidence of meteorological drought which is ultimately thought to have an impact on the productivity of rainfed paddy.

\section{Result and discussion}

\subsection{Frequency of meteorological drought events in each sub-district of Gunungkidul Regency during $2001-2019$}

Drought frequency states the number of drought events during a certain time [25]. Drought events in Gunungkidul Regency were identified through the results of the SPI classification at 18 observation rain stations showing moderately dry, severely dry and extremely dry classes during the period $2001-2019$. The SPI processing used in the identification of meteorological drought is the 6-month SPI scenario (SPI- 6). The processing results show that each rain station has a varying frequency of meteorological drought events as shown in Table 2.

Table 2. Frequency of meteorological drought events in Gunungkidul Regency 2001 - 2019

\begin{tabular}{clc}
\hline Num & Name of Sub-districts & $\begin{array}{r}\text { Meteorological Drought } \\
\text { Events (Month) }\end{array}$ \\
\hline 1 & Paliyan & 50 \\
2 & Purwosari & 46 \\
3 & Tepus & 43 \\
5 & Karangmojo & 43 \\
6 & Semin & 43 \\
7 & Saptosari & 42 \\
8 & Wonosari & 41 \\
9 & Patuk & 40 \\
10 & Semanu & 38 \\
11 & Gedangsari & 38 \\
12 & Nglipar & 38 \\
13 & Ngawen & 37 \\
14 & Rongkop & 36 \\
15 & Playen & 35 \\
16 & Tanjungsari & 33 \\
17 & Panggang & 32 \\
18 & Girisubo & 31 \\
\hline
\end{tabular}

During 2001 - 2019, Paliyan Sub-district was the sub-district that experienced the most meteorological drought events, reaching 50 drought events, followed by Purwosari Sub-District with 46 drought events. Tepus, Karangmojo and Semin sub-districts are the third subdistricts that have the highest number of drought events. The three sub-districts have the same number of drought events, namely as many as 43 drought events. The districts with the least number of drought events are Girisubo and Ponjong Sub-districts with 31 and 30 drought events, respectively.

Frequency of drought events in each of these subdistricts when viewed spatially does not show a pattern because the frequency of occurrence is spread throughout all sub-districts in Gunungkidul Regency. Paliyan and Purwosari Sub-districts as the sub-districts with the highest number of meteorological droughts are located on the south side of Gunungkidul Regency. However, Purwosari Sub-district is directly adjacent to the east side with Panggang Sub-district, which is the district with the third lowest number of droughts in Gunungkidul Regency. Likewise, the Sub-districts of Tepus, Karangmojo and Semin which are the third sub-districts with the highest number of droughts have different spatial positions. Tepus Sub-district is located in the southern part, Karangmojo Sub-district is located in the middle part, while Semin Sub-district is located in the northern part of Gunungkidul Regency.

The absence of a spatial pattern in the variation in the frequency of meteorological drought events is the same as the results of [21] which examines meteorological drought in Bangkalan Regency where meteorological drought events spread randomly in every part of the region so that they do not show a certain spatial pattern. This is more because the parameters used in the meteorological drought analysis only come from rainfall. According to [26], the other possible factors that influence the development of drought are differences in conditions of wind speed and direction, evapotranspiration, temperature, land cover, land use, water retention and regional landforms. These factors can affect the decrease in rainfall so that there are differences in the frequency of the number of meteorological droughts in various areas in Gunungkidul Regency.

\subsection{Distribution of meteorological drought every month with the worst meteorological drought in Gunungkidul Regency during 2001 - 2019}

Spatial analysis of the distribution of meteorological drought in Gunungkidul Regency during the years of 2001 - 2019 emphasized the occurrence of the worst drought in each month. The worst drought events in each month were identified from the matrix table of the results of the SPI data processing in the SPI-6 scenario every month during the years $2001-2019$. The worst drought for 12 months from January to December was not always the same year because every year it produced months with different frequency, duration and intensity of drought. To simplify the analysis, the analysis is divided into two subsubsections from January to June and July to December. 


\subsubsection{Analysis of the worst meteorological drought every month during January - June}

The worst meteorological drought in January during 2001 - 2019 occurred in January 2007. Figure 2 shows the distribution of each drought class from moderately dry, severely dry and extremely dry which has a varying area which is sequentially reaching an area of $205.12 \mathrm{~km}^{2}$, $463.73 \mathrm{~km}^{2}$, and $542.88 \mathrm{~km}^{2}$. The total area of drought events that occurred in January 2007 reached $1211.73 \mathrm{~km}^{2}$ or about $82.1 \%$ of the total area of Gunungkidul Regency. Some other areas were observed to have a normal class with an area of $246.6 \mathrm{~km}^{2}$. In addition, there is a small area that has a wet class with an area of $18.27 \mathrm{~km}^{2}$ or about $1.2 \%$ of the total area of Gunungkidul Regency.

Drought in January 2007 continued, resulting in February 2007 being the worst drought that occurred in Gunungkidul Regency in February during the period 2001 - 2019. The drought in February 2007 began to reduce the area of drought from the previous month where the total drought area of which originally reached $82 \%$ to $79.4 \%$ of the total area of Gunungkidul Regency or around 1171.70 $\mathrm{km}^{2}$. Extremely dry drought class experienced a significant decrease from around 36\% in January 2007 to $25.7 \%$ in February 2007.

The worst meteorological drought that occurred in January and February 2007 is thought to have been due to a decrease in rain due to the El Nino phenomenon. According to the result of [27] in Klaten Regency which is geographically located directly adjacent to Gunungkidul Regency also showed a similar situation where there was a significant decrease in rainfall in January 2007 due to the influence of the El Nino phase during late 2006 to early 2007.
The drought in March 2010 was the worst drought that occurred in March during 2001 - 2019. The total area of drought that occurred in March 2010 reached 1238.2 $\mathrm{km}^{2}$ or about $83.9 \%$ of the total area of Gunungkidul Regency. The percentage of the area of drought occurrence is almost similar to the area that occurred in January 2007 but both have spatially different area patterns as shown in Figure 2.

The worst drought in the following month occurred in April 2010 which was a continuation of the drought in March 2010. Compared to the previous month, the total area of drought in April 2010 decreased from $1238.19 \mathrm{~km}^{2}$ to $1081.05 \mathrm{~km}^{2}$ or around $73,2 \%$ of the total area of Gunungkidul Regency. This indicates a reduction in drought intensity from the previous month.

The next worst drought occurred in May 2005. Different from the previous worst months, drought in May 2005 had a smaller total area of only $692.81 \mathrm{~km}^{2}$ or $46.9 \%$ of the total area of Gunungkidul Regency. Figure 2 shows the extent of drought during the month of May 2005. It can be seen that the areas experiencing drought are spread only in a small part of the north, middle and south of Gunungkidul Regency, including the Sub-districts of Semin, Nglipar, Karangmojo, Wonosari, Playen, Paliyan and Saptosari.

June 2005 became June with the worst drought throughout 2001-2019 and was a continuation of the drought in May 2005. The drought in June 2005 experienced an increase in drought events from the previous month with a total area of $1164.14 \mathrm{~km}^{2}$ or around $78,9 \%$ of the total area of Gunungkidul Regency. The expansion of the drought indicates that the intensity of drought in the Gunungkidul Regency has increased.

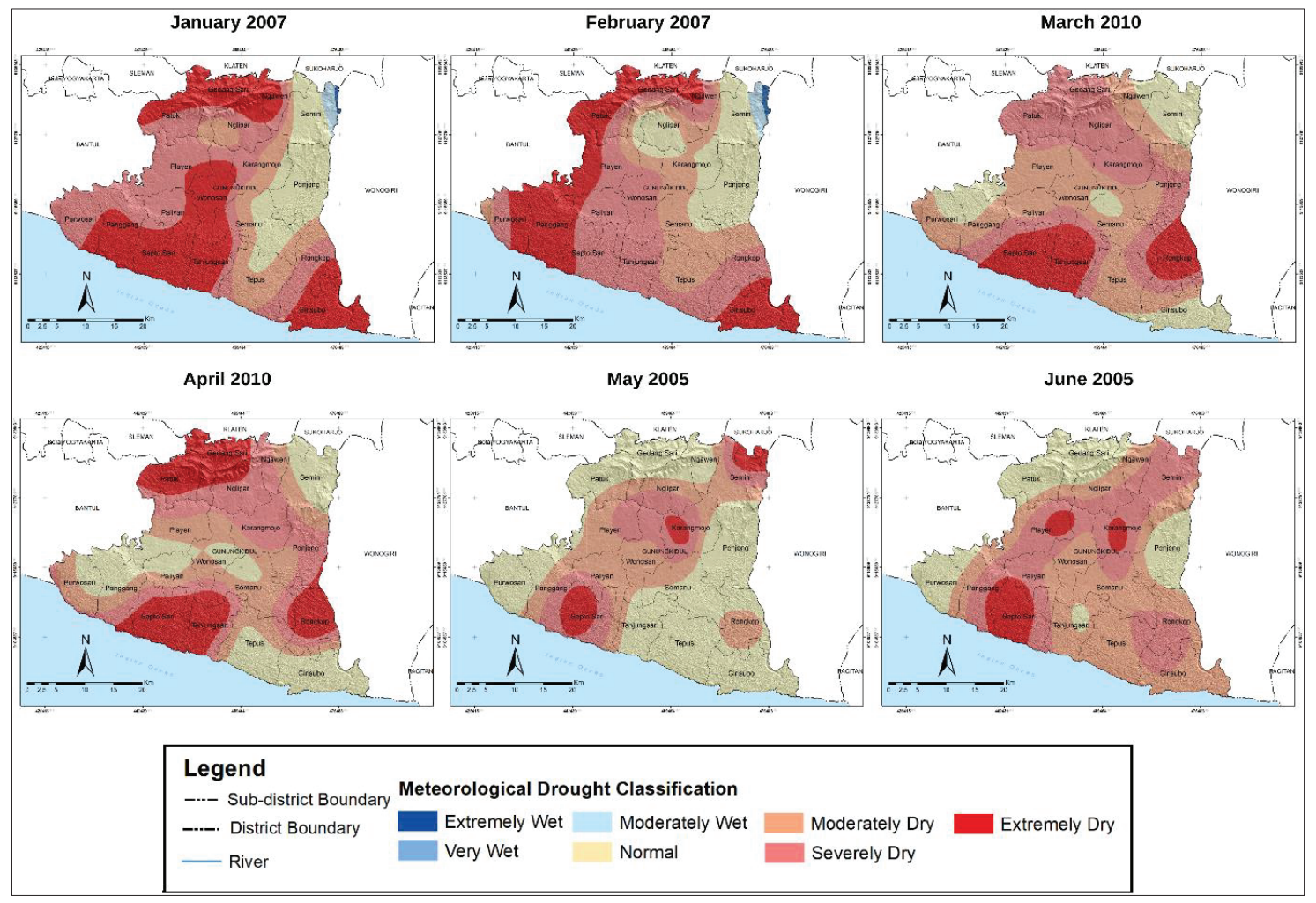

Fig. 2. The worst meteorological drought in January - June in Gunungkidul Regency during $2001-2019$ 


\subsubsection{Analysis of the worst meteorological drought every month during July - December}

The drought in May and June 2005 turned out to still continue until July 2005 so that it became the month of July with the worst drought than any other July during 2001 - 2019. Compared to the previous month, the drought in July 2005 began to experience a decrease in drought intensity. This can be seen from the total area of drought which began to decline to $906.23 \mathrm{~km}^{2}$ or $61 \%$ of the area of Gunungkidul Regency. The spatial pattern of drought events shown in Figure 3 is not much different from the spatial pattern of drought events in the previous month. However, in the southern part of Gunungkidul Regency, which includes Tepus Subistrict and parts of Semanu and Rongkop Sub-districts, the extent of drought events has narrowed. Meanwhile, the area of drought in other parts tends to be stagnant and there is not much visible change compared to the previous month.

The drought in August 2008 became the next worst drought. In that month, an area of $48.7 \%$ of the area of Gunungkidul Regency or an area of $718.68 \mathrm{~km}^{2}$ experienced drought. The distribution of drought events in August 2008 is shown in Figure 4.8. The thing that distinguishes the drought distribution pattern in August 2008 compared to the worst months before is the condition of the drought area which tends to strengthen on the east side of Gunungkidul Regency including Ponjong Sub-district and Rongkop Sub-district with a extremely dry drought class. This condition is certainly different from the period of the worst months previously discussed where the eastern side of Gunungkidul Regency rarely experiences drought events.

The drought conditions in August 2008 were strengthened by [28] which examined the 3-Month SPI in Gunungkidul Regency where it was said that August 2008 was one of the months with the worst drought index in the short term throughout 2007-2016. According to [28], the results of the SPI-3 in August 2008 were extremely concentrated in several areas such as Patuk, Ngawen, Gedangsari, Ponjong, Semanu, Semin, Karangmojo, Rongkop and Tepus. This pattern is slightly different from the SPI-6 produced in this study. However, this can be an indication that August 2008 was the month of August with the worst drought in both the short- and medium-term drought scenarios. One of the causes of the decrease in rain in August 2008 was due to the positive Indian Ocean Dipole [29,30].

The drought that occurred in September 2019 resulted in a drought area of $1181.46 \mathrm{~km}^{2}$ or about $80 \%$ of Gunungkidul Regency. Classes of drought that occurred included normal, moderately dry and severely dry with the percentage of area to the area of Gunungkidul Regency respectively reaching $18.5 \%$, $44.1 \%, 35.9 \%$. In that month, no extremely dry class was observed and there were a small number of areas with wet class reaching $1.13 \%$.

The drought in October 2019 experienced an expansion of drought events compared to the previous month in the same year. The increase in the area of drought occurred quite significantly where the area of drought reached $1445.58 \mathrm{~km}^{2}$ or about $97.9 \%$ of the area of Gunungkidul Regency experienced drought. It can be seen in Figure 3 that drought almost occur in all areas in Gunungkidul Regency.

An increase in the intensity of drought in October 2019 occurred in all of Gunungkidul Regency where all areas that were observed to be normal in the previous month experienced drought events from moderately dry to severely dry. The normal observed area only occurs on the northeast side of Gunungkidul Regency which in the previous month was observed in the wet classification. An increase in drought intensity also occurred on the western side of the southern part of Gunungkidul Regency, precisely in parts of Purwosari and Panggang Sub-districts. The area has increased from being severely dry to extremely dry. The widespread drought that occurred in 2019 coincided with the weakening of the SOI value which is an indication of a stronger El Nino. This results in a longer dry season. In years with a normal period, September should have increased rainfall. However, in 2019 from September to October there was a meteorological drought which indicated a decrease in rainfall and a longer dry season.

The worst drought that occurred in the following month occurred in November 2006 which was also the month with the worst drought among all months during 2001 - 2019. The entire area of Gunungkidul Regency experienced drought events and all of them were classified as moderately to extremely dry. The area classified as severely dry into the widest drought class reaches $1081.92 \mathrm{~km}^{2}$ which is then followed by moderately dry and extremely dry drought class with an each area of $358.95 \mathrm{~km}^{2}$ and $35.29 \mathrm{~km}^{2}$.

Drought conditions in November 2006 in Gunungkidul Regency which became the most severe of all months during 2001-2019 were in line with several studies on meteorological droughts conducted in the Java and Bali regions. Result of [21] on meteorological drought in Bangkalan Regency during $2001-2015$ also resulted in the widest drought in November 2006 where the entire Bangkalan Regency experienced drought events. Likewise, with [23] stated that the meteorological drought in Central Java during 1980 2010 where it was said that November 2006 was one of the months with the most severe drought because it almost occurred in all regencies in Central Java. Also, the result of [31] on the island of Bali also indicated the same thing where in November 2006 most of Bali experienced drought in all SPI scenarios.

The worst drought in December still occurred in the same year as the previous month. The difference is that the area of drought began to decrease with an area of $1125.85 \mathrm{~km}^{2}$ or equivalent to $76.3 \%$ of the total area of Gunungkidul Regency. It can be seen in Figure 3 that a number of areas that initially experienced drought began to return to normal as happened in the eastern and north-eastern parts of Gunungkidul Regency including Ponjong, Semin and parts of Semanu and Rongkop Subdistricts. Weakening conditions of drought intensity were also observed in the northern part where areas that were previously classified as severely dry began to show 
changes to moderately dry classification, such as in the Sub-districts of Gedangsari, Ngawen, Nglipar and parts of Patuk Sub-district. The same thing also happened in the southern part covering the Sub-districts of Paliyan, Purwosari, Tepus and Saptosari. As for the southeast, precisely in Girisubo Sub-district, there is an increase in drought intensity.

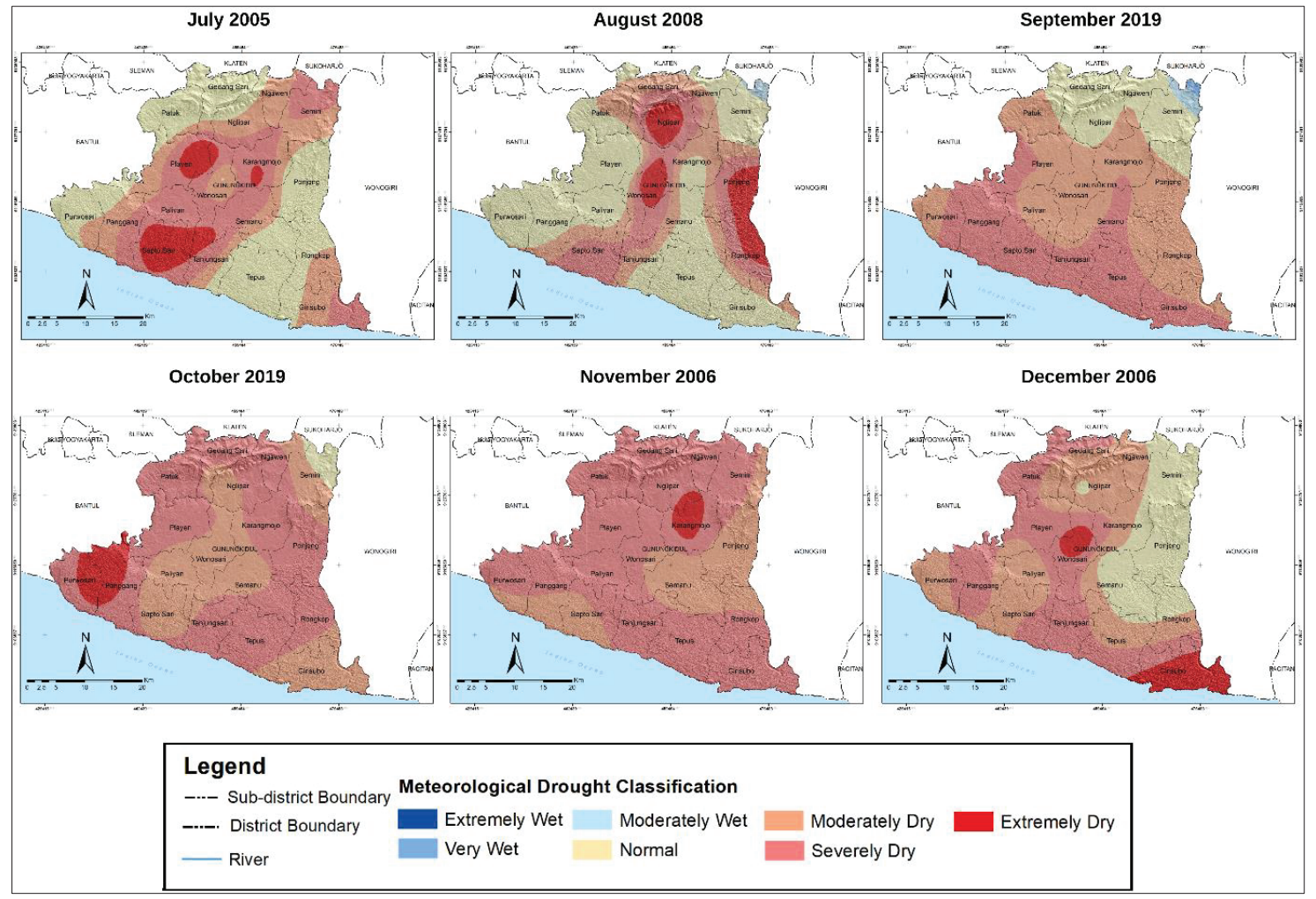

Fig. 3. The worst meteorological drought in July - December in Gunungkidul Regency during 2001 - 2019

\subsection{Extreme meteorological drought in Gunungkidul Regency during 2001 - 2019}

Extreme drought events are drought conditions that are classified as extremely dry droughts. The extreme drought that occurs in the medium term from the SPI-6 scenario indicates an indication of reduced surface water resources, reduced irrigation discharge and agricultural impacts and is an early warning before the occurrence of further agricultural and hydrological droughts [7]. The results of the analysis of the drought in Gunungkidul Regency during 2001 - 2019 showed that the extent of extreme drought varied. Not all years produce extreme drought areas as discussed in the previous discussion points where drought areas in the worst months often indicate large areas of drought without any areas with extremely dry droughts.

Table 3 shows the area of the largest extreme drought that occurred during $2001-2019$. The extreme drought occurred in January 2007 with extreme drought reaching $542.88 \mathrm{~km}^{2}$. The area of extreme drought that year was the largest compared to other extreme droughts with a significant difference in area. This can be seen from the area of extreme drought which then only has an area of $378.79 \mathrm{~km}^{2}, 343.51 \mathrm{~km}^{2}, 336.08 \mathrm{~km}^{2}$ and 228.08 $\mathrm{km}^{2}$. The spatial analysis of each of these areas has been discussed in the previous discussion points along with meteorological drought events in other drought classifications.

Extreme drought can be related to the geomorphology of landforms and land use in analyzing the potential impacts that occur [23]. All extreme drought events in 2007 and 2010 as shown in Table 3 were concentrated in the southern and northern parts of Gunungkidul Regency. If these results are analyzed from the perspective of geomorphological conditions in Gunungkidul Regency, the southern part is a karst area while the northern part is a Baturagung hill area. Extreme drought in the southern region can threaten the existence of seasonal lakes to meet the residents' domestic water needs, while drought in the northern region can result in a decrease in springs and river flow. In relation to land use, extreme drought in all areas in Gunungkidul Regency can threaten dryland agriculture because the area of agricultural land spreads over almost the entire area of Gunungkidul Regency.

Temporarily, meteorological drought in Gunungkidul Regency is more common during the wet month period than the dry period. The area of Gunungkidul Regency generally has a C3 and D3 climate type which has a wet period that occurs around November - April. The widespread meteorological drought conditions classified as extreme drought during 
the wet period indicated a significant decrease in rainfall from normal conditions. This can threaten agriculture because the wet period is identical to the planting period in Gunungkidul Regency, resulting in an increase in the impact of drought. One of the factors that cause the decrease in rainfall is the El Nino phenomenon.

Table 3 also shows that the incidence of extreme drought in Gunungkidul Regency coincided with the year of El Nino. However, the extreme drought is more dominant when El Nino is weak to moderate. When a strong El Nino is observed no significant drought occurs. In fact, no months with the worst drought events were observed during a strong El Nino of 2015. This is an indication that the decrease in rain in Gunungkidul Regency is not only influenced by El Nino or it could also indicate that the increase in meteorological drought depends on the time and duration of El Nino events.

Table 3. Extreme meteorological drought in Gunungkidul Regency 2001 - 2019

\begin{tabular}{|c|l|r|r|c|}
\hline Num & Month (Result of SPI-6 Scenario) & \multicolumn{1}{|c|}{ Year } & Area $\left(\mathrm{km}^{2}\right)$ & ENSO Phase \\
\hline 1 & August - January & 2007 & 542.878 & Moderate El Nino \\
\hline 2 & September - February & 2007 & 378.79 & Weak El Nino \\
\hline 3 & October - March & 2007 & 343.51 & Weak El Nino \\
\hline 4 & November - April & 2010 & 336.08 & Moderate El Nino \\
\hline 5 & December - May & 2010 & 228.06 & Weak El Nino \\
\hline
\end{tabular}

\subsection{Meteorological drought relationship with rainfed paddy productivity in Gunungkidul Regency}

The analysis of rainfed paddy productivity in Gunungkidul Regency is illustrated through an annual graph during 2001 - 2019 in Figure 4 - Figure 6 . This is to see fluctuations in rainfed paddy productivity, especially when various strength fluctuations occur during the ENSO phases. The year of occurrence of ENSO is represented by the annual SOI value while the SPI-4 graph value is used to represent the meteorological drought that occurs. The graph of the value of rainfed paddy productivity is represented by the several sub-districts which represents sub-districts with varying locations from the southern, central and northern sides of Gunungkidul Regency covering Panggang, Patuk, Karangmojo, Paliyan and Ngawen sub-districts.

Through the graph in Figure 4 - Figure 6 it can be see when there is a strengthening of El Nino as the annual SOI value decreases, it is followed by a decrease in the value of SPI-4 which then has an impact on the decrease in rainfed paddy productivity. This condition was clearly seen, especially in 2004, 2005, 2007, 2017 and 2019. Most of these years were the year when the El Nino period was moderate.

Different things were shown when there was a strong El Nino in 2015. In 2015, it was observed that paddy productivity did not experience a significant change in line with the condition of the SPI-4 value in that year nor was it too different from the previous year. This is related to the previous discussion points where the 2015 El Nino did not have much effect on the decrease in monthly rainfall in Gunungkidul Regency because El Nino occurred during the dry month. The stagnation of rainfed paddy productivity in 2015 is also in accordance with [27] that the conditions of rainfed paddy productivity in Klaten Regency which also shows no significant change from previous years due to rainfall conditions as the main irrigation source for lowland paddy. dry season did not experience a significant decrease when El Nino occurred in 2015.

Related to paddy varieties, Ciherang and Situbagendit are evenly distributed throughout the region [32]. One of the adaptations in Gunungkidul Regency was the provision of water resources for horticultural irrigation. Drilling wells are provided especially in the central and northern parts of Gunungkidul Regency which have shallow groundwater $[33,34]$. Therefore, variations in the relationship between drought and paddy productivity may vary in each region due to different type of paddy varieties and the development of adaptation in each sub-district.

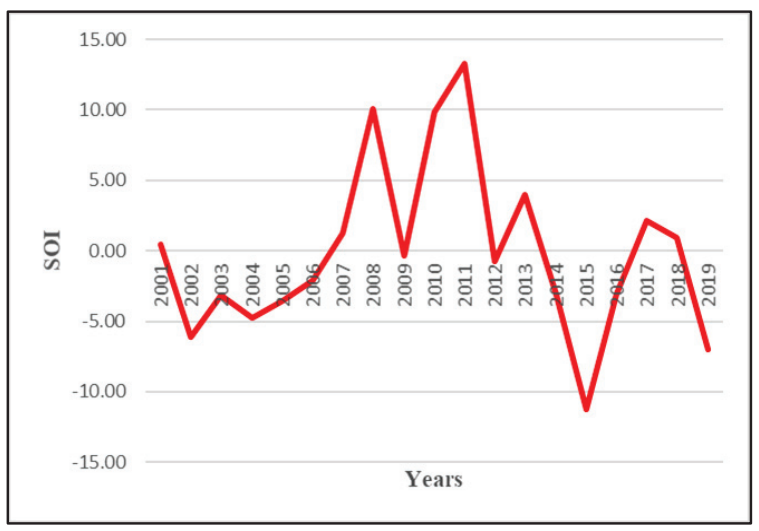

Fig. 4. Southern oscillation index as an indicator of the ENSO phase during $2001-2019$. 


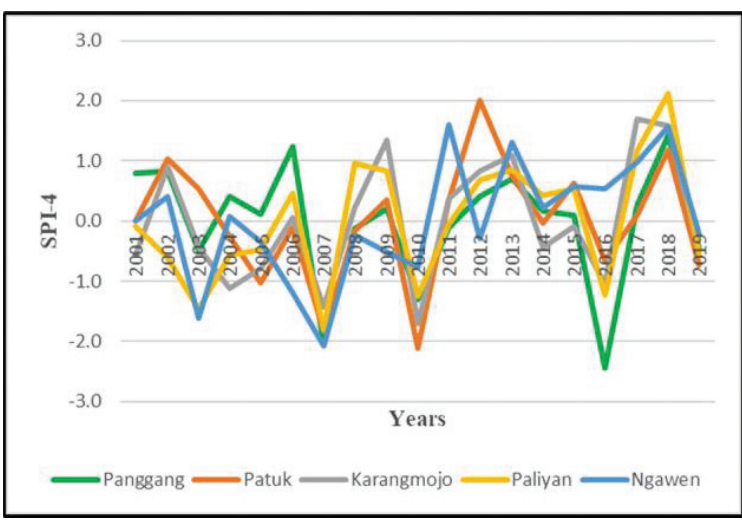

Fig. 5. SPI-4 in January as an indicator of drought during agricultural season in Gunungkidul Regency during 2001 2019

\subsection{Rainfed paddy productivity during Normal, El Nino and La Nina years in Gunungkidul Regency}

Analysis of rainfed paddy productivity in Gunungkidul Regency was also carried out spatially through the distribution of the average rainfed paddy productivity during Normal, El Nino and La Nina periods so that they could be compared temporally and spatially. The results of the average productivity values during Normal, El Nino and La Nina periods are shown in Figure 7. The average productivity in each period is then divided into five classes from very low, low, medium, high and very high to facilitate the representation into map. The intervals of productivity values (n) in tons/ha for each class sequentially are: Very Low $(\mathrm{n}<3.83)$, Low $(3.83$ $<\mathrm{n}<4.14)$, Medium $(4.14<\mathrm{n}<4.46)$, High $(4.46<\mathrm{n}$ $<4.77)$ and Very High $(n>4.77)$.

Figure 7 shows the spatial conditions of the average value of rainfed paddy productivity in Gunungkidul Regency during the normal, El Nino and

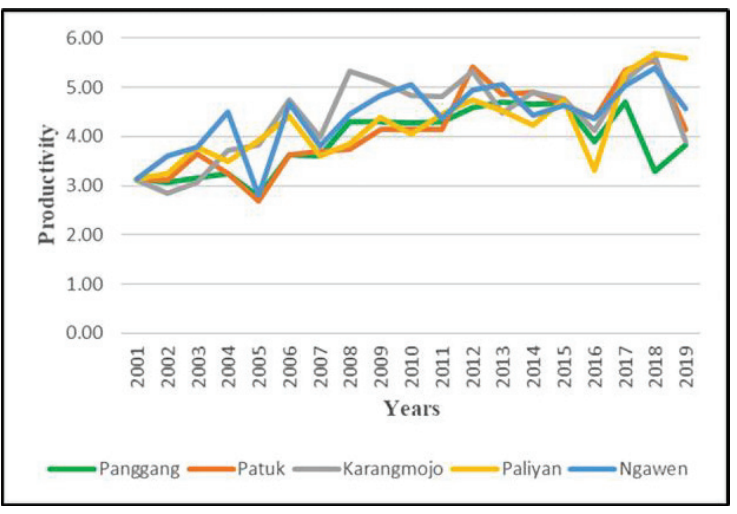

Fig.6. Rainfed paddy productivity of several sub-district of annual first growing season (October - January) in Gunungkidul Regency during $2001-2019$.

La Nina phases. During El Nino, most areas in Gunungkidul Regency experienced a decrease in productivity from normal years where many subdistricts were observed which were classified as low and very low productivity values, especially in sub-districts located in the southern part of Gunungkidul Regency. This can happen because the southern region is a karst region that has deep groundwater, making it difficult to build irrigation wells for agricultural needs, so that the decrease in rain due to El Nino can directly impact irrigation.

On the other hand, during the La Nina, there was an increase in the value of paddy productivity in all areas of Gunungkidul Regency. It was observed that there were no sub-districts that were classified as very low as happened during the Normal and El Nino periods. There is a significant difference in productivity during the El Nino and La Nina phases in line with [35] that many agricultural sectors in developing countries have a high dependence on climate so that extreme climate, especially from the ENSO - El Nino, can reduce its productivity.

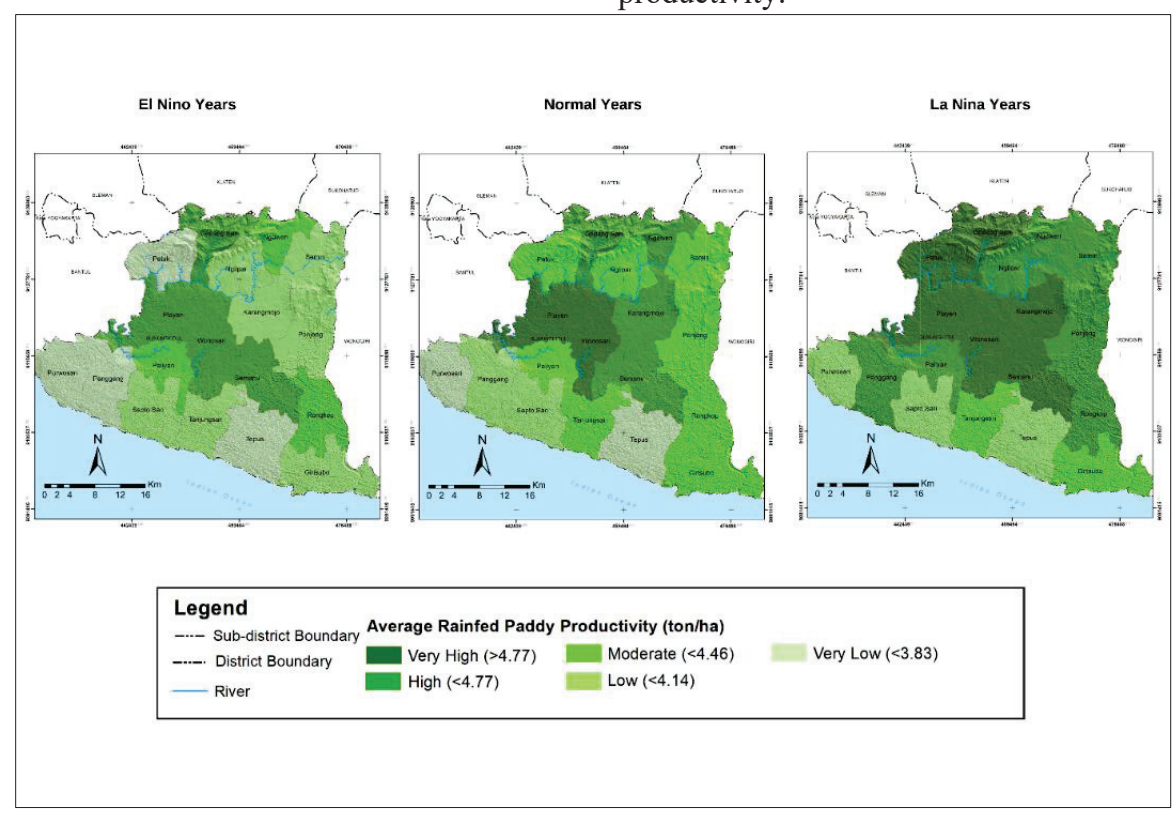

Fig. 7. The worst meteorological drought in July - December in Gunungkidul Regency during $2001-2019$ 


\subsection{Resource management recommendations based on research results}

The condition of the majority of people who have a high dependence on agricultural products in Gunungkidul Regency is recommended to be able to carry out an intercropping system, especially in areas that have a significant relationship between ENSO, drought and rainfed paddy productivity. Intercropping systems can minimize crop failures compared to monoculture systems because through intercropping the failure of one commodity can be replaced with other commodities that are planted together [36]. In relation to intercropping, one way that can minimize the impact of subsequent drought is through a paddy agroforestry system where paddy is planted intercropping with other seasonal crops which are then planted with border trees such as Teak, Silk Tree and Mahogany [34]. The agroforestry system can be a nature-based solution in minimizing drought where limiting trees planted with seasonal agricultural commodities can maintain the temperature of the surrounding microclimate and can increase the ability of the soil to capture and hold water and reduce evaporation so as to maintain soil moisture. better for the growth of annual crops such as paddy [37,38].

One of the most important things in overcoming various impacts of climate anomalies, including ENSO that causes meteorological drought, especially in the agricultural sector, is the adaptability of each farmer. However, the adaptation of farmers will be hampered in their development without support from the government [39]. Therefore, the strengthening of community adaptation that can be carried out through structural forms of mitigation is through the provision of adequate irrigation infrastructure for the community. Increasing water availability can be done by storing rainwater, preserving land cover, and other building engineering to be able to control surface runoff [40]. In addition, it is important for the government to provide access to nutrients and better paddy varieties to anticipate stronger drought intensity in the future where traditional methods may no longer be able to cope. Often farmers still maintain traditional adaptation procedures because agricultural inputs such as nutrients, fertilizers and seeds are expensive with insufficient availability making it difficult for farm households to reach [36].

\section{Conclusion}

The widest meteorological drought during 2001 - 2019 occurred in November 2006 where the entire area of Gunungkidul Regency experienced a drought. Meteorological drought tends to occur more frequently during the month during the wet period than during the dry period. The highest frequency of drought events occurred in Paliyan Sub-district with the number of months of drought reaching 50 months while the lowest frequency of drought events occurred in Ponjong Subdistrict with the number of dry months reaching 30 months.
Rainfed paddy productivity in Gunungkidul Regency with meteorological drought has a positive relationship. During El Nino years, paddy productivity decreases and vice versa when La Nina occurs, productivity will increase. However, not all sub-districts have the same relationship between paddy productivity and meteorological drought. The difference in the paddy varieties and development of different adaptations in each sub-district may causes variations in the relationship in each region.

Further research related to drought in Gunungkidul Regency can examine the condition of the development of community resilience to the various impacts of drought that have often occurred for years in Gunungkidul Regency. The difference in the development of adaptation to drought in various regions may be one of the differences in the variation in the impact of drought, especially on the agricultural sector.

This research is part of the 2021 UGM RTA grant on behalf of Dr. Emilya Nurjani M.Si. Thank you for those who have helped with this research as well as all parties from the Agriculture and Food Office of Gunungkidul Regency, the Central Statistics Agency of Indonesia, National Mapping Agency of Indonesia and Australian Bureau of Meteorology who have published the data so that it can be used for the purposes of this research.

\section{References}

1. L.Maheswara, Jurnal Manajemen Bencana Kekeringan, 01, 1-13 (2016)

2. R. L. Naylor, D. S. Battisti, D. J. Vimont, W. P. Falcon, M. B. Burke, 104 (19), 7752-7757 (2007)

3. S.M. Vicente-Serrano, E. Aguilar, R. Martínez, et al, Clim Dyn 48, 405-427 (2017)

4. Sudibyakto, Manajemen Bencana di Indonesia Ke Mana? (2011)

5. W. Cai, S. Borlace, M. Lengaigne, P. V. Rensch, M. Collins, G. Vecchi, A. Timmermann, A. Santoso, M. J. McPhaden, L. $\mathrm{Wu}, \mathrm{M}$. H. England, G. Wang, E. Guilyardi, F.-F. Jin, Nature Climate Change, 4(2), 111116 (2014)

6. F. Kogan, Monitoring Drought from Space and Food Security, In book: Remote Sensing for Food Security, 75-113) (2019)

7. K. Jenkins, R. Warren, Theoretical and Applied Climatology, 120(1-2), 41-54 (2015)

8. Badan Penelitian dan Pengembangan Pertanian, Pedoman Umum Adaptasi Perubahan Iklim Sektor Pertanian (2011)

9. Sugihardjo, Model Adaptasi Ekologi Petani Sebagai Strategi Pengelolaan Usahatani Akibat Perubahan Iklim (Kasus Di Daerah Aliran Sungai Cemoro, Jawa Tengah), in Doctoral Dissertation, Universitas Sebelas Maret, Surakarta (2016)

10. E. Runtunuwu, H. Syahbuddin, Jurnal Tanah Dan Iklim, 26, 1-12 (2007) 
11. F. Apriani, Y. D. Setianingsih, U. M. P. Arum, K. A. Susanti, S. I. Wicaksono, A. Faruk, Khazanah, 6(2), 13-22 (2007)

12. Badan Pusat Statistik, Kabupaten Gunungkidul Dalam Angka 2019 (2019)

13. I. Wredaningrum, Jurnal Bumi Indonesia, 3(4), 1-10, (2014)

14. A. Cahyadi, H. Nugraha, F. Nucifera, In E. Sudarmadji, Haryono, T.N. Adji, M. Widyastuti, R. Harini, E. Nurjani, A. Cahyadi, H. Nugraha (Eds.), Ekologi Lingkungan Kawasan Karst Indonesia: Menjaga Asa Kelestarian Kawasan Karst Indonesia ( 2013)

15. F. Prawaka, A. Zakaria, S. Tugiono, Jurnal Rekayasa Sipil Dan Desain, 4(3), 397-406 (2016)

16. World Meteorological Organization, Standardized Precipitation Index User Guide (2012)

17. Z. Pei, S. Fang, L. Wang, W. Yang, Water, 12(7) (2020)

18. B. Sutaryo, S. Widodo, Kajian Keragaan Beberapa Varietas Unggul Baru Padi Gogo di Lahan Sub-Optimal Gunungkidul, In Prosiding Seminar Nasional Lahan Suboptimal 2018, Palembang 18-19 Oktober 2018 "Tantangan Dan Solusi Pengembangan PAJALE Dan Kelapa Sawit Generasi Kedua (Replanting) Di Lahan Suboptimal”, 8, 978-979 (2019)

19. P. Dahal, N. S. Shrestha, M. L. Shrestha, N. Y. Krakauer, J. Panthi, S. M. Pradhanang, T. Lakhankar, Natural Hazards, 80(3), 19131932 (2016)

20. R. Zhao, H. Wang, C. Zhan, S. Hu, M. Ma, Y. Dong, Theoretical and Applied Climatology, 139(3-4), 1363-1377 (2020)

21. K. A. Cahyono, Kajian Kekeringan Meteorologis di Kabupaten Bangkalan Jawa Timur, In Bachelor Thesis, Universitas Gadjah Mada, Yogyakarta (2018)

22. D. Manatsa, G. Mukwada, E. Siziba, T. Chinyanganya, Theoretical and Applied Climatology, 102(3), 287-305 (2010)

23. H. Nurrohmah, Analisis Kekeringan Meteorologis Menggunakan Standardized Precipitation Index (SPI) Di Provinsi Jawa Tengah, In Bachelor Thesis, Universitas Gadjah Mada, Yogyakarta (2017)

24. A. H. Payab, U. Türker, Environmental Earth Sciences, 78(10), 1-19 (2019),

25. J. Spinoni, G. Naumann, H. Carrao, P. Barbosa, J. Vogt, International Journal of Climatology, 34(8), 2792-2804 (2014)

26. U. Šebenik, M. Brilly, M. Šraj, Acta Geographica Slovenica, 57(1), 31-49 (2017)

27. I. I. Putri, E. Nurjani, Jurnal Bumi Indonesia, 1-12 (2018)
28. S. Sulastri, Analisis Indeks Curah Hujan untuk Identifikasi Daerah Rawan Kekeringan di Kabupaten Gunungkidul, In Bachelor Thesis, Universitas Gadjah Mada, Yogyakarta (2017)

29. A. Fadholi, Jurnal Ilmu Lingkungan, 12(2), 43 (2013)

30. Y. Ikawati, Kekeringan Sampai November Akibat IOD Positif (2008)

31. M. A. Yosilia, Analisis Hubungan El Nino dengan Kekeringan Meteorologis Menggunakan SPI (Standardized Precipitation Index) di Pulau Bali, In Bachelor Thesis, Universitas Gadjah Mada, Yogyakarta (2014)

32. Riyandoko, E. Mulyoutami, Kiprah Agroforestri 24, 9-10 (2016)

33. A. Anshori, D. Riyanto, Suradal, Journal of Agri-Food, Nutrition and Public Health, 1(2), 55-61 (2020)

34. J. Nugroho, M. Zid, M. Miarsyah, Journal of Environmental Sustainability Management, 438-447 (2020)

35. A. Limsakul, Environment and Natural Resources Journal, 17(4), 30-42 (2019)

36. M. Maryana, S. Priyanto, Peran Pertanian Tumpangsari Untuk Mendukung Kedaulatan Pangan, In Prosiding Seminar Nasional Kedaulatan Pangan, Fak, Pertanian Universitas Pembangunan Nasional Veteran Yogyakarta (2012)

37. J. Cook, 3 Steps to Scaling Up Nature-Based Solutions for Climate Adaptation (2020)

38. M. Kumar, H. Singh, In: S. Dhyan, A. Gupta, M. Karki, Disaster Resilience and Green Growth (2020)

39. A.B. Sekaranom, E. Nurjani, F. Nucifera, Sustainability, 13(13), 70692021

40. I. Narulita, Jurnal Tanah Dan Iklim, 41(1), 4560 (2017) 